\title{
Upstream-downstream Connectivity: An Overview of Hydrological and Ecological Functions in relation to the Churia-Terai Conservation in Nepal
}

\author{
Shambhu Paudel ${ }^{1}$ and Reecha Basnet ${ }^{2}$
}

\begin{abstract}
The ChuriaTerai (CT) is interlinked by the Churia range, Bhabar and Terai, where Terai exist as granary basket of the country and the Churia and Bhabar is the recharge zone of Terai. Changing environment of the Churia range has directly affected the condition of upstream and downstream. To recommend the appropriate watershed management linking upstream and downstream on this landscape, functional analysis were carried out using ecological and hydrological parameters based on secondary literatures. For the proper management of the watershed and its alarming cause of deterioration, understanding upstream and downstream linkages or process is must. Deforestation leads to climate change (temperature and precipitation) and watershed deterioration, which has become the aggravating factor for landslide and soil erosion in upstream and flood in the downstream. The paper highly stressed development of conceptual framework with clear functional activities based on integrated watershed management approach linking the upstream-downstream hydro-ecological phenomena. Thus the paper recommends integrated watershed management with a clear policy which helps to focus priorities and manages its bio-physical condition in a sustainable basis.
\end{abstract}

Key Words: upstream, downstream, integrated watershed, Churia, Terai, Nepal.

Paudel S., Basnet R. (2018): Upstream-downstream Connectivity: An Overview of Hydrological and Ecological Functions in relation to the ChuriaTerai Conservation in Nepal. Forestry: Journal of Institute of Forestry, Nepal. No. 15: page 87 to 96.

${ }^{1}$ Tribhuvan University, Institute of Forestry, Pokhara Campus, Nepal and School of Natural Resources and the Environment, The University of Arizona, Tucson, USA, Author corresponding email address: spaudel@iofpc.edu.np

${ }^{2}$ Tribhuvan University, Institute of Forestry, Hetauda Campus, Nepal 


\section{Introduction}

The Churia-Terai (CT) comprises of Churia range, Bhabar and Terai which are intimately linked either geographically or ecologically. The Churia range is also known as Siwalik hill range that covers $1000 \mathrm{~km}^{2}$ east-west along the foothills with altitude range from 914 to $2000 \mathrm{~m}$ from the sea level and occupies $12.84 \%$ of the country's land (FRA/DFRS 2014a). The flat terrain created due to the deposition of rough sediments between Mahabharat hills and Churia range is Bhabar which covers $4 \%$ of the country's land. Terai is a low land region in Southern Nepal which is known as the 'grain basket' and lies south of outer foothills of Siwalik Hills and covers 23\% of the country's land (Department of Survey 2001).The Churia range, the Bhabar and the Terai regions cannot be separated when we talk about the conservation and management as it covers $34.46 \%$ of the country's land. Out of total land of CT, $47.16 \%$ of land is covered by forest, shrub- land and grassland (FRA/DFRS 2014b). Out of the total CT land covered by forest, $24 \%$ is under "protected area" with $18 \%$ core area and $6 \%$ buffer zone. The rest $76 \%$ have been managed as the community forest (CF), leasehold forest and government-managed forests (President Chure Terai Madhesh Development Board - PCTMDB 2017).

The Churia hills are geologically young, fragile and environmentally sensitive hills (LRMP 1968). Their soils are originated from soft rocks which is loosely formed and have high erodibility and fragile in nature (RECOS 1997; Pokhrel et al. 2002; BPP 1995). Sheet erosion, gully erosion, landslides and stream bank erosion prevails in Churia range and depending on its land use intensity, per year; 780 to 20,000 ton of soil per square kilometer is washed down (Mishra, Bista 1998.). Due to erosion in upstream, downstream faces a serious problem of siltation turning productive lands into unproductive Riverbeds. Eroded material raises the River bed of Churia originating Rivers which changes the River course and cause flood.

In addition to this, the climate of the $\mathrm{CT}$ region ranges from sub-tropical to warm temperature characterized by hot and sub- humid summers, intense monsoon rain and cold dry winters (PCTMDB 2017). The windward side of Churia range receives more rainfall than the lee-ward side. With the light of these, geographically varied country like Nepal has to focus on the management as its landscape links upstream and downstream directly. Environmental degradation in the Churia region is not only limited in the upstream areas rather it has created more severe disasters in 
the downstream areas of the Terai region as well. The importance of upstream and downstream linkages are important in biological processes as upstream respond to the complex interactions of geomorphic and hydrologic processes, upstream are important source of sediment, water and nutrients and organic matter for downstream system, and movement of aquatic biota also takes place and supports downstream food web and it enhances ecosystem. Managing upstream and downstream linkages helps in controlling natural calamities (landslides and flood) and maintaining water quality. This paper highlights the importance of upstream and downstream connectivity in relation to CT conservation in Nepal by understanding ecological and hydrological significance between two components.

\section{Materials and Methods}

This paper is entirely based on secondary literatures available for the conservation and management of the CT. Only the journal articles and technical reports published by concerned authorities in Nepal were considered as secondary literature. To be more specific, two functional parameters were identified to be discussed on the paper- ecological and hydrological. Ecological parameter includes land covers or ecological significance and hydrological component discuss about run off, temperature and precipitation analysis. Upstream and downstream connectivity analysis will be based on these two factors.

\section{Results}

\section{Ecological conditions}

The CT is important for biodiversity as it is the habitat of the flagship mammals such as tiger, elephant, rhino and wild-buffalo and as there is the presence of abundant floral species. Out of total 118 ecosystems of Nepal (BBP 1995), 14 ecosystem lies in the Churia hills and 12 lies in the Terai region (PCTMDB 2017). The forest of this landscape consists of 281 tree species, 186 shrub species and 322 species of herbaceous plant. Out of the total landscape Bhabar and Terai region have 164 tree species, 72 shrub species, 109 herbaceous plant species, 30 climber species and 5 epiphyte. This region has 65 species of mammals in which 8 are "endangered" and listed in the IUCN Red List and the 15 are under protection by government. In terms of biodiversity, 1,308 species out of the total 1,988 species of flora and fauna found in Nepal exist in the CT alone (NBS 2014-2020). This region is also important in the conservation point of view as 321 species out of the total 493 endangered 
species of flora and fauna found in Nepal inhabit in this region alone (PCTMB 2017). According to land cover mapping, forest covers $40.36 \%$ of total area of Nepal and other wooded land covers $4.38 \%$ and other land $55.26 \%$ of the country (FRA/DFRS 2014). Out of the total Forest, $23.04 \%$ lies in Churia and $6.90 \%$ lies in Terai. Out of the total other wood land, Terai and Churia regions share $1.47 \%$ of its total. Nepal has $48.19 \%$ of agricultural land (PCTMB 2017).

With the light of ecological coverage of the Churia region, it is well documented as important recharge zone of ground water that feeds agricultural land and forests of the Terai, home to iconic species such as tigers and rhinos (BPP 1995). Due to the intimate linkage of Churia and Terai, land cover plays a heroic role to protect the downstream (ie. Terai). Thus land cover plays a heroic role in protecting the fragile state of land which induces the natural calamities which directly protects the downstream from deposition, flood and landslides. Land cover generally influence local hydrology through evapotranspiration. They also affect infiltration processes into underlying soil and ground cover through their root systems and organic humus layer, which contributes to controlling erosion dynamics. The local climate also influences the processes by which forest and land use affect the hydrological cycle (Hibbert 1967; Wilk 2002) also helps in maintain the climate of the region which manages the hydrologic processes of the area.

\section{Hydrological condition}

\section{Precipitation trend analysis}

The available precipitation patterns for CT, generally analyzed for 1970 to 2009, are variable with higher annual rainfall in the Eastern and Central region (DHM 2009). The total annual rainfall varies from minimum of $1138 \mathrm{~mm}$ to the maximum of $2671 \mathrm{~mm} /$ year. The average annual rainfall is between 1500 to $3200 \mathrm{~mm}$ throughout the landscape. The average trend of mean precipitation is decreasing in CT (Singh 2012). The precipitation pattern is dominated by the presence of the monsoon circulation and its interaction with the topography. The winter season is the driest period of the year but with a high variability, where most precipitation falls during the monsoon season. Winter rain also varies with topography and climate. The extreme rainfall distribution is quite different from the annual and seasonal distribution. The Terai belt receives less seasonal rainfall compared to Churia range which receives intensive rainfalls. Overall, eastern, central, western and far western 
development regions illustrated positive trend in annual precipitation. Some small pocket areas observed over $30 \mathrm{~mm} /$ year increase in annual precipitation (DHM 2015).

\section{Temperature trend analysis}

The average maximum temperature is found to be between $28.2^{\circ} \mathrm{C}$ and $31.8^{\circ} \mathrm{C}$ and average minimum temperature is found to be between $15.8^{\circ} \mathrm{C}$ and $20.4^{\circ} \mathrm{C}$. The extreme maximum temperature is found up to $44.5{ }^{\circ} \mathrm{C}$ in summer and extreme minimum temperature is up to $0^{\circ} \mathrm{C}$.Temperature differs according to land topography. The highest temperatures are recorded in the Terai and Churia regions. Maximum temperature is in increasing trend in large magnitude than the minimum temperature in almost all the seasons. The mean annual minimum temperature trend is higher in low altitude Terai and Churia range and lower in high altitude region while the trend pattern is reverse in mean annual maximum temperature with higher in high altitude region and lower in low lying Terai plains (DHM 2015).

\section{Case study:}

Understanding upstream and downstream connectivity matters in the field for the conservation of $C T$

This case study was taken from SANDEE Working Paper No. 88-14, which was conducted in the Koshi Basin of Nepal. In this paper, a choice experiment was undertaken to examine differences in demand for local environmental services among downstream and upstream watershed users. The question of this study is whether the demand for these local services is sufficient to allow villagers to manage watersheds for improved provision of these services and sustain any investments that may be required. To address this concern, researchers have used non-market valuation techniques to identify the shadow value of time for conservation activities. This study estimates the opportunity cost of labor using non-market valuation techniques and use this information to derive social benefits from conserving local environmental services. It even highlighted the difference in preferences for watershed services among household and even found that social benefits from watershed management are 1.4 to 2.2 times higher when estimated in labor terms versus monetary terms. This study suggested that locational differences matter. Down-stream community members, who practice commercial vegetable farming, have a higher demand for watershed services and are willing to pay a 
third more than upstream farmers for these services. This case study inferred that downstream communities are willing to pay for conservation or management of upstream of watersheds to get sustainable ecosystem services. This clearly indicates that upstream and downstream ecological and hydrological functions should be understood clearly if we are working for the CT.

\section{Discussion}

Susceptibility to ecological and hydrological risk has been a prime issue on this landscape as it comprises young and fragile geomorphic and the proper management is must. Young fragile topography is receiving cloudburst type of rain immediately after driest period, which could facilitate the process of high runoff with maximum amount of sediment loads. However, recent land covers status across the Churia region reducing the magnitude and rate of such effects. In addition to this, increasing trend of maximum temperature will be a significant contributing factor for changing the local hydrological functions; through changing hydrological cycle and micro climate. This immediately seeks profound and meaningful management plans for CT. Management of this highly sensitive landscape should be based on ecological and hydrological performance rather than submitting outputs. In addition to this, deforestation is continuously being the main problem which hinders the ecosystems and water resources. Consequently, this could lead to alter the ecological and hydrological functions of upstream landscape. Therefore, nature and condition of upstream is needed to be managed properly addressing social dynamics, so that downstream life does not get affected. For the proper management of this landscape different ecological, social and economical activities must be carried out as the declining stage of the Churia range will directly affect the status of Terai region. Taking the declining productivity and protective stages of Churia and the Terai, Government of Nepal has established the The President Chure-Terai Madhesh Conservation Development Board for its sustainable management. Even the Terai Arc Landscape Strategy 2015-2025 has also been doing the conservation activities sensing the declining status of this landscape. Department of Soil Conservation and Watershed Management also work on the conservation and management of watershed. However, proper and meaningful co-operation between concerned stakeholders is not in action to achieve the goal of sustainability.

Land cover, run-off, precipitation and temperature are vital factors that affect overall 
functions of CT connectivity and the contribution of these factors on watershed is valuable on hydrology. As the recharge and discharge of the water of watershed depends on the condition of these factors, the hydrology trend plays an important role in watershed management. So, the analysis of its trend will serve as asset for district level planning and implementation of projects. To analyze the temperature trend, seasonal and time series of the surface maximum and minimum temperature trend for the maximum period is essential on annual and seasonal basis. Importantly, the extreme events should be analyzed and understood to minimize the effects in the downstream. These kind of events are noticed since a couple of years back. So while developing the outlet for watershed management, the aggravating factors and the upstream and downstream linkage that may affect the watershed must be kept in account for an effective result by linking CT.

It is pre-dominantly assumed that watershed degradation is a natural process which occurs at a much faster rate unless conservation initiated (MoFSC 2009). In order to manage watershed effectively and sustainably people's participation is must. A proper project's intervention is necessary. To manage a CT, choosing the watershed area to be managed is important that combined the linkages between upstream and downstream. Proper identification and then delineate and map the watershed's boundaries and the smaller drainage basins within the watershed is must. Inventory must be carried out of every component that affects the watershed like land use, land cover, soils, drainages, and resources around watershed and pollution sources. Areas of erosion and the quality of water must be identified and tested in series of temporal scales. The most degraded one should be kept in attention. The degree of public education and participation in the planning process can greatly influence the success of watershed management. Watershed planning should also identify and include the partners, or "stakeholders," in the watershed. There are many ways to involve and educate the public in watershed management. The formation of citizen review groups and advisory committees can gain public support from the watershed and are essential components to a successful, community-based, and locally led effort. These community-based groups and committees can also provide the means to keep the project going once the plan has been finalized to make sure that recommended actions are taken. It will also be helpful to identify a watershed coordinator to help in this effort. It is important to establish a schedule with milestones and some sort of committee to ensure that projects proceed in time. 
A monitoring program should also be established to measure success through data gathering, which will assist the follow up programme for checking the management accuracy. Development of local partnerships is must as it can also lead to greater awareness and support from the general public. Once individuals become aware of and interested in the watershed management of CT, they often become more involved in decision-making as well as hands-on protection and restoration efforts. Through such involvement watershed can be managed completely and meaningfully. Watershed management planning should also determine what the opportunities are to reduce pollution or address other pressing environmental issues, prioritize those opportunities, and identify a time frame for accomplishing pollution reduction and resource and habitat improvements.

\section{Conclusion}

The CT is the fragile landscape of the country which is susceptible to landslide and erosion. In depth, risk scores should be calculated immediately based on current ecological and hydrological functions of CT connectivity including downstream sensitivity indicators. The CT is rich in biodiversity, however natural calamities occurs in the Churia range directly hinders the Bhabhar Terai status. Partly the Rivers of this zone are snow fed and precipitation contributes for stream flow. The upstream and downstream linkage is important in management basis of this landscape. The precipitation and temperature for the Churia is greatly sensitive compare to the Terai and its impacts on downstream site are uncertain because of its recent trend. Therefore, impacts of upstream events and activities in the downstream events should be understood, and managed. This seeks to use an integrated systems analysis approach combining upstream and downstream ecological process or phenomena. Management of water resources both in individual catchments and across River basins should be done. This landscape is highly affected by deforestation and its impacts. The role of forest and other vegetation in, and the impacts of deforestation and cultivation on run off flow and soil erosion are complex, and it is important to draw conclusions for conservation basis. The paper highly stressed development of conceptual framework based on integrated watershed management approach understanding the upstream-downstream linkages which requires people's participation and the coordination with the governmental and non-governmental bodies. 


\section{Literature Cited}

Biodiversity Profiles Project (1995): Biodiversity Profile of the Terai and Siwalik Physiographic Zone. Technical Publication No.12. TA to Establishment of Biodiversity Profile, Nepal. Department of National Parks and Wildlife Conservation. Kathmandu, Nepal.

Department of Survey (DoS) (2001): National Topographical Base Maps. Department of Survey. Kathmandu, Nepal.

FRA/DFRS (2014): Churia Forests of Nepal (2011 - 2013): Forest Resource Assessment Nepal/Project. Department of Forest Research and Survey (FRA/ DFRS). Babarmahal, Kathmandu, Nepal

FRA/DFRS (2014): Terai Forests of Nepal (2010 - 2012). Forest Resource Assessment Nepal. Project/Department of Forest Research and Survey (FRA/ DFRS).Babarmahal, Kathmandu

Government of Nepal, Ministry of Environment, Asian Development Bank (2009):

Nepal Climate Draft Portal (1970- 2009). Department of Hydrology and Meteorology (DHM). Babar Mahal, Kathmandu, Nepal.

Government of Nepal, Ministry of Science and Technology, Department of Hydrology and Meteorology (2015): Draft Report: Study of Climate and Climatic Variation over Nepal. Nepal.

Hibbert A. R. (1967): Forest Treatment Effects on Water Field. Pergamum. Oxford.

Land Reform Mapping Project (1986): LRMP. Kathmandu, Nepal.

Ministry of Forests and Soil Conservation (MoFSC) (2015): Strategy andA c t i o $n$ Plan 2015-2025, Terai Arc Landscape, Nepal. Ministry of Forests and Soil Conservation. Singha Durbar, Kathmandu, Nepal.

Ministry of Forests and Soil Conservation (MoFSC) (2014): Nepal National

Biodiversity Strategy And Action Plan 2014-2020. Ministry of Forests and Soil Conservation. Singha Durbar, Kathmandu, Nepal.

Mishra S. B., Bista S. (1998): A Compendium on Environment Statistics 1998 Nepal. Nepal.

PCTMB (2017): President Churia- TaraiMadhesh Conservation and Management Master Plan. GoN, Kathmandu, Nepal.

Pokhrel S., Tiwari S. (2002): Prospects of Restoration of the Critical Siwaliks Ecosystem: Lesson Learnt from Ilam Siwaliks. Proceedings of International Seminar on Mountains, Kathmandu. March 6-8, 2002.

RECOS (1997): The Greening of the Siwalik Himalayas. In the Himalayan 
Environment, Pressure- Problem: 12 Year Research. P.63-77.

Sharma K.P. (1997): Role of Melt Water in Major River Systems of Nepal. Snow and Glacier Hydrology. No. 218.

Singh B.K. (2012): Assessment of the Upstream Churia Hills and Downstream Terai Plain Linkage: An Environmental Services Perspective. BankoJankari. Vol. 20, No. 1, Nepal.

Wilk J. (2002): Stimulating the Impacts of Land-use and Climate Change on WaterResource Availability for a Large South Indian Catchment Hydrol Sci. 47(1): 19-30 